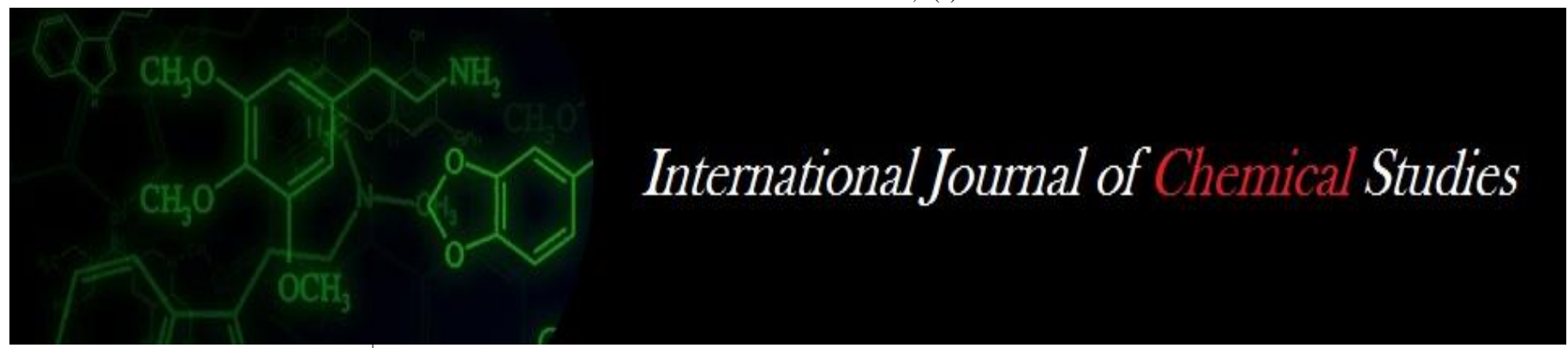

P-ISSN: 2349-8528

E-ISSN: 2321-4902

IJCS 2020; 8(1): 2207-2211

(C) 2020 IJCS

Received: 28-11-2019

Accepted: 30-12-2019

R Naga Lakshmi

Scientist (Hort.), Horticultural

Research Station, Kovvur, West

Godavari District, Andhra

Pradesh, India

M Lakshminarayana Reddy

Dean of Horticulture, Dr. YSR

Horticultural University,

Venkataramannagudem, West

Godavari District, Andhra

Pradesh, India

AVD Dorajee Rao

Associate Professor

(Horticulture), College of

Horticulture,

Venkataramannagudem, West

Godavari District, Andhra

Pradesh, India

BVK Bhagavan

Principal Scientist (Hort) \&

Head, Horticultural Research

Station, Kovvur, West Godavari

District, Andhra Pradesh, India

\section{P Subbaramamma}

Assistant Professor (Plant

Physiology), College of

Horticulture,

Venkataramannagudem, West

Godavari District, Andhra

Pradesh, India

\section{K Uma Krishna}

Associate Professor (Statistics), College of Horticulture,

Venkataramannagudem, West Godavari District, Andhra

Pradesh, India

\section{Effect of plant bioregulators on quality, productivity and profitability of tuberose cv. Prajwal}

\author{
R Naga Lakshmi, M Lakshminarayana Reddy, AVD Dorajee Rao, BVK \\ Bhagavan, P Subbaramamma and K Uma Krishna
}

DOI: https://doi.org/10.22271/chemi.2020.v8.i1ag.8597

\begin{abstract}
In order to explore the possibility of improving the quality, productivity and profitability of tuberose (Polianthes tuberosa L.) cv. Prajwal using different plant bioregulators, an experiment was conducted during 2015-16 and 2016-17 at Horticultural Research Station, Kovvur of Dr. YSR Horticultural University, Andhra Pradesh. Five plant bioregulators (Gibberellic acid, Benzyl Adenine, Salicylic acid, Ethephon and Spermidine) each at two concentrations in addition to water spray as control were evaluated in randomised block design with three replications. The results revealed that the foliar sprays of plant bioregulators at 30 and 60 days after sprouting of bulbs, significantly influenced floret quality, floret yield and bulb yield. Significantly maximum length $(6.12 \mathrm{~cm})$, diameter of floret $(4.34 \mathrm{~cm}), 100$ floret weight $(210.85 \mathrm{~g})$, floret yield $\left(12.02 \mathrm{t} \mathrm{ha}^{-1}\right)$ and bulb yield $\left(11.57 \mathrm{t} \mathrm{ha}^{-1}\right)$ was recorded in the plants sprayed with $\mathrm{GA}_{3}$ at $200 \mathrm{ppm}$ over control. The same treatment recorded the highest benefit - cost of 3.02 .
\end{abstract}

Keywords: Tuberose, bioregulators, floret yield, bulb yield, economics

\section{Introduction}

Tuberose is (Polianthes tuberosa L.) a member of Asparagaceae family. In India, it is one of the important fragrant flowers commercially cultivated in an area of 7.77 thousand ha with a production of 40.22 thousand tonnes (NHB, 2015) ${ }^{[14]}$. Tuberose is widely used in making flower garlands which are offered to the god or used as wedding ornaments and also used in perfumery industries. Owing to the availability of improved cultivars, the area under this crop is expanding at a fast pace. It has a good potential for export to many countries like Malaysia, Singapore, Sri Lanka and Gulf.

In horticultural crops, the use of plant bioregulators (PBRs) is one of the scientific approaches to explore the possibilities to enhance the productivity and profitability. Low concentration of plant bioregulators are applied externally at a suitable developmental stage to boost the plant signaling which finally leads to enhanced growth and crop yield (Srivastava et al., 2016) ${ }^{[25]}$. It is apparent that crop responses to PGRs vary and that the response is dependent on the concentration of PGR used. A low concentration increases the photosynthetic potential of leaves and translocation of photosynthates to sink, while high concentration adversely affects these traits. Sink potential is determined after growth and flowering and phytohormones have a prominent role in modifying it. Phytohormones have been implicated in various aspects of the control of photosynthesis and distribution of photosynthates to sink. They have been found engaged in increasing photosynthetic and yield potential of several crops, and increasing source-sink interactions (Khan et al., 2007) ${ }^{[9]}$. Taking these facts under consideration an experiment entitled "Effect of plant bioregulators on quality, productivity and profitability of tuberose cv. Prajwal" was conducted.

\section{Materials and Methods}

The experiment was carried out at Horticultural Research Station, Kovvur, West Godavari district, Andhra Pradesh, during 2015-2016 and 2016-2017 with the tuberose cv. Prajwal. The soil was black alluvial, having $\mathrm{pH} 7.6$, low in organic carbon $(0.48 \%)$ and available nitrogen
R Naga Lakshmi

Scientist (Hort.), Horticultural

Research Station, Kovvur, West

Godavari District, Andhra

Pradesh, India 
(188.6 $\left.\mathrm{kg} \mathrm{ha}^{-1}\right)$ and medium in available phosphorus $(20.5 \mathrm{~kg}$ $\left.\mathrm{ha}^{-1}\right)$ and high in available potassium $\left(543.9 \mathrm{~kg} \mathrm{ha}^{-1}\right)$. Healthy tuberose bulbs with more than $2.0 \mathrm{~cm}$ diameter were used as planting material. Bulbs were planted at a spacing of $30 \mathrm{~cm} \mathrm{x}$ $30 \mathrm{~cm}$ in the experimental plots of $2.4 \times 2.4 \mathrm{~m}$ size. At the time of final ploughing, well decomposed farmyard manure @ $25 \mathrm{t} \mathrm{ha}^{-1}$ was incorporated into the experimental plots. Nitrogen, phosphorus and potassium were applied @ 200:200:200 kg ha $\mathrm{kg}^{-1}$ in the form of urea, single super phosphate and muriate of potash respectively. Entire dose of phosphorus and potassium was applied as basal dose and nitrogen was applied in three split doses at 30,60 and 90 days after planting. Irrigations were given at an interval of one to two weeks depending on the soil moisture. All other intercultural practices and plant protection measures were followed as per the recommended schedule. Eleven treatments comprising of five bioregulators at two different concentrations were tested in randomized block design with three replications. The treatments were $\mathrm{T}_{1}: \mathrm{GA}_{3} 100 \mathrm{ppm}, \mathrm{T}_{2}$ : $\mathrm{GA}_{3} 200$ ppm, $\mathrm{T}_{3}$ : SA 50 ppm, T T $_{4} \mathrm{SA} 100 \mathrm{ppm}, \mathrm{T}_{5}$ : BA 50 ppm, $\mathrm{T}_{6}$ : BA $100 \mathrm{ppm}, \mathrm{T}_{7}$ : Ethephon $250 \mathrm{ppm}, \mathrm{T}_{8}$ : Ethephon $500 \mathrm{ppm}, \mathrm{T}_{9}$ : Spermidine $50 \mathrm{ppm}, \mathrm{T}_{10}$ : Spermidine $100 \mathrm{ppm}$ and $\mathrm{T}_{11}$ : Water spray (Control). As per the treatments respective bioregulators were sprayed two times at 30 and 60 days after sprouting (DAS) of bulbs on the foliage. Observations on floret quality, floret and bulb yield were recorded and pooled the data. The data was statistically analyzed as per the methods given by Panse and Sukhatme (1989) ${ }^{[16]}$. Economics was worked out on the basis of prevailing market prices of inputs and outputs.

\section{Results and Discussion \\ Floret quality}

Quality of florets in terms of floret length, floret diameter, 100-floret weight registered marked variation with application of plant bioregulators (Table 1). Maximum floret length was noticed with $\mathrm{GA}_{3}$ treatment over all other plant bioregulators under study. The highest floret length was observed in $\mathrm{GA}_{3}$ $200 \mathrm{ppm}(6.12 \mathrm{~cm})$ sprayed plants whereas the lowest value was recorded in control $(5.37 \mathrm{~cm})$ which was on par with ethephon $500 \mathrm{ppm}(5.42 \mathrm{~cm})$. The elongating effect of gibberellin in many plant organs was reported by Audus (1972) ${ }^{[3]}$ which might have caused increased floret length in tuberose. The present results are in agreement with the observations made by Rani and Singh (2013) ${ }^{[18]}$, Kurve $(2016)^{[12]}$ in tuberose.

Significant differences were noticed among different bioregulating chemicals for floret diameter. Among different bioregulating chemicals sprayed, maximum floret diameter was observed in $\mathrm{GA}_{3} 200 \mathrm{ppm}(4.34 \mathrm{~cm})$ whereas minimum floret diameter was recorded in control $(3.81 \mathrm{~cm})$ which was on par with ethephon $500 \mathrm{ppm}(3.84 \mathrm{~cm})$. Application of $\mathrm{GA}_{3}$ 200 ppm significantly increased the floret diameter. In addition to its role in early floral initiation, gibberellins also play a role in floral development (Brooking and Cohen, 2002) [4]. The above results are in accordance with the findings of Kurve (2016) ${ }^{[12]}$ in tuberose. $\mathrm{GA}_{3}$ followed by SA also enhanced the floret diameter. The present results are in accordance with the earlier findings of Anwar et al. (2014) ${ }^{[2]}$, Khodakhah et al. (2014) ${ }^{[10]}$ in tuberose. SA might have altered the biophysical properties of cell wall and increased the floret size. However, Ethephon 500 ppm treated plants slightly reduced the florets size both in terms of length and diameter than ethephon $250 \mathrm{ppm}$ treated plants. Similarly, Singh and Bijimol (2001) ${ }^{[20]}$ observed decrease in floret diameter with increase in ethrel concentration in tuberose cv. Double.

Plant bioregulators differed significantly with respect to 100 floret weight. Among the plant bioregulators, 100-floret weight was maximum in $\mathrm{GA}_{3} 200$ ppm (210.85 g) sprayed plants while it was minimum in control $(184.95 \mathrm{~g})$ which was on par with ethephon 500 ppm (186.73 g). Increase in 100floret weight in $\mathrm{GA}_{3}$ treated plants might be attributed to the fact that $\mathrm{GA}_{3}$ enhances flower dimensions $(6.12 \mathrm{~cm} / 4.34 \mathrm{~cm})$ by drawing more photosynthates to the flower as a consequence of intensification of the sink (Zieslin et al., 1974) ${ }^{[26]}$. Floret yield (100-floret weight) was minimum in control which was on par with ethephon 500 ppm treatment. Singh et al. (2010) ${ }^{[24]}$ also reported similar results at 1000 ppm ethephon in tuberose cv. Double. It could be due to reduction in floret size $(5.42 \mathrm{~cm} \mathrm{/} 3.84 \mathrm{~cm})$ at higher concentration of ethephon.

Table 1: Effect of plant bioregulators on floret quality and yield of tuberose cv. Prajwal

\begin{tabular}{|c|c|c|c|c|}
\hline Treatments & Length of floret $(\mathrm{cm})$ & Diameter of floret $(\mathrm{cm})$ & 100-floret weight (g) & Floret yield $\left(\mathrm{t}\right.$ ha $\left.^{-1}\right)$ \\
\hline $\mathrm{T}_{1}: \mathrm{GA}_{3} 100 \mathrm{ppm}$ & 6.02 & 4.26 & 207.15 & 11.81 \\
\hline $\mathrm{T}_{2}: \mathrm{GA}_{3} 200 \mathrm{ppm}$ & 6.12 & 4.34 & 210.85 & 12.02 \\
\hline $\mathrm{T}_{3}: \mathrm{SA} 50 \mathrm{ppm}$ & 5.88 & 4.16 & 202.34 & 11.54 \\
\hline $\mathrm{T}_{4}: \mathrm{SA} 100 \mathrm{ppm}$ & 5.91 & 4.19 & 203.45 & 11.60 \\
\hline $\mathrm{T}_{5}: \mathrm{BA} 50 \mathrm{ppm}$ & 5.75 & 4.07 & 197.90 & 11.28 \\
\hline $\mathrm{T}_{6}: \mathrm{BA} 100 \mathrm{ppm}$ & 5.80 & 4.11 & 199.75 & 11.39 \\
\hline T7: Ethephon $250 \mathrm{ppm}$ & 5.59 & 3.96 & 192.35 & 10.97 \\
\hline $\mathrm{T}_{8}$ : Ethephon $500 \mathrm{ppm}$ & 5.42 & 3.84 & 186.73 & 10.51 \\
\hline $\mathrm{T}_{9}:$ Spermidine $50 \mathrm{ppm}$ & 5.64 & 4.00 & 194.20 & 11.07 \\
\hline $\mathrm{T}_{10}:$ Spermidine $100 \mathrm{ppm}$ & 5.69 & 4.03 & 196.05 & 11.18 \\
\hline $\mathrm{T}_{11}$ : Water spray (Control) & 5.37 & 3.81 & 184.95 & 10.86 \\
\hline Mean & 5.74 & 4.07 & 197.79 & 11.29 \\
\hline S.Em & 0.02 & 0.01 & 0.67 & 0.14 \\
\hline C.D. at $5 \%$ & 0.06 & 0.04 & 1.97 & 0.41 \\
\hline
\end{tabular}

GA3: Gibberellic acid; SA: Salicylic acid; BA: Benzyl Adenine

\section{Floret yield}

Foliar spray of plant bioregulators significantly influenced floret yield ha ${ }^{-1}$ (Table 1). Highest floret yield ha-1 was recorded in $\mathrm{GA}_{3} 200 \mathrm{ppm}$ sprayed plants $\left(12.02 \mathrm{t} \mathrm{ha}^{-1}\right)$ and it was on par with $\mathrm{GA}_{3} 100 \mathrm{ppm}$ sprayed plants $\left(11.81 \mathrm{t} \mathrm{ha}^{-1}\right)$. While the lowest floret yield $\mathrm{ha}^{-1}$ was observed in ethephon
$500 \mathrm{ppm}$ sprayed plants $\left(10.51 \mathrm{t} \mathrm{ha}^{-1}\right)$ and it was statistically on par with control $\left(10.86 \mathrm{t} \mathrm{ha}^{-1}\right)$. Similar results were reported by Padaganur et al. (2005) ${ }^{[15]}$ in tuberose. Gibberellic acid is known to improve the photosynthetic efficiency through its influence on photosynthetic enzymes, light interception and enhanced nutrient use efficiency in 
plants. The integrated mechanisms enhance source potential and redistribution of photosynthates by $\mathrm{GA}_{3}$ results in increased sink strength (Khan et al., 2007) ${ }^{[9]}$. Salicylic acid also enhanced floral attributes and floret yield next to $\mathrm{GA}_{3}$ treatments. Similar results were obtained by Anwar et al. (2014) ${ }^{[2]}$, Khodakhah et al. (2014) ${ }^{[10]}$ in tuberose. This might be due to greater improvement in the net photosynthetic activity and its partitioning into florets which lead to better productivity in SA treated plants. Exogenous application of SA increased the endogenous content of SA and positively influenced the plant growth and flowering (Kim et al., 2009) [11]. Moreover, salicylic acid might have stimulated the flowering in plants by inducing a greater uptake of nutrients, through its influence on development of extensive and elaborative root systems (Machado et al., 2007) ${ }^{[13]}$. Lowest floret yield $\mathrm{ha}^{-1}$ was recorded with ethephon $500 \mathrm{ppm}$ foliar spray. However, ethephon at $250 \mathrm{ppm}$ significantly increased floret yield ha-1 than control. This might be attributed to the fact that, plants have the capacity to respond to ethylene in a biphasic manner, i.e., with growth promotion at lower doses and growth reduction at higher doses as explained by Pierik et al. $(2007)^{[17]}$.

\section{Bulb parameters}

Foliar spray of different plant bioregulators registered significant variation with regard to various bulb parameters and bulb yield (Table 2). Maximum number of bulbs clump ${ }^{-1}$ was recorded in plants treated with BA $100 \mathrm{ppm}$ (8.16) as compared to control (7.16) which was on par with ethephon $500 \mathrm{ppm}$ (7.23). Similar results were obtained by Aier et al. (2015) ${ }^{[1]}$, Chopde et al. (2015) ${ }^{[6]}$ in gladiolus. Singh (1999) [21] reported highest number of bulbs plant ${ }^{-1}$ with 100 ppm kinetin in tuberose. This effect of kinetin might be attributed to its role in an increase in cell division in apical meristem and cambial tissue or elimination of apical dominance (Chase, 1989) ${ }^{[5]}$. Further, Benzyl adenine is also known to promote cell division and lateral bud development, which might have resulted in an increase in number of daughter bulbs as well as bulblets clump ${ }^{-1}$. Moreover, Singh et al. (2008) ${ }^{[23]}$ found more number of bulbs clump ${ }^{-1}$ in tuberose with the application of $\mathrm{GA}_{3} 200 \mathrm{ppm}$ which is also evident in the present study. The number of bulbs clump ${ }^{-1}$ were more in plants treated with $\mathrm{BA}$ followed by $\mathrm{GA}_{3}$. Foliar spray with $\mathrm{GA}_{3}$ at $200 \mathrm{ppm}$ significantly enhanced the weight of bulbs clump $^{-1}(135.67 \mathrm{~g})$ over control $(119.01 \mathrm{~g})$ while it was on par with ethephon $500 \mathrm{ppm}(120.15 \mathrm{~g})$. The increase in weight of the bulbs clump ${ }^{-1}$ with the application of $\mathrm{GA}_{3}$ could be attributed to an increase in leaf area plant $^{-1}$ which further increased the photoassimilates. These assimilates were transported to the daughter bulbs, thereby increased the bulb weight clump ${ }^{-1}$. Similar findings have also been reported by Shanker et al. (2011) ${ }^{[19]}$, Singh et al. (2013) ${ }^{[22]}$ in tuberose.

Table 2: Effect of plant bio regulators on bulb parameters and yield of tuberose cv. Prajwal

\begin{tabular}{|c|c|c|c|}
\hline Treatments & Number of bulbs clump- ${ }^{1}$ & Weight of bulbs clump ${ }^{-1}(\mathrm{~g})$ & Bulb yield $\left(\mathrm{t} \mathrm{ha}^{-1}\right)$ \\
\hline $\mathrm{T}_{1}: \mathrm{GA}_{3} 100 \mathrm{ppm}$ & 7.83 & 133.29 & 11.37 \\
\hline $\mathrm{T}_{2}: \mathrm{GA}_{3} 200 \mathrm{ppm}$ & 7.88 & 135.67 & 11.57 \\
\hline $\mathrm{T}_{3}: \mathrm{SA} 50 \mathrm{ppm}$ & 7.66 & 127.34 & 10.86 \\
\hline $\mathrm{T}_{4}: \mathrm{SA} 100 \mathrm{ppm}$ & 7.73 & 128.53 & 10.96 \\
\hline $\mathrm{T}_{5}: \mathrm{BA} 50 \mathrm{ppm}$ & 8.02 & 130.20 & 11.10 \\
\hline $\mathrm{T}_{6}: \mathrm{BA} 100 \mathrm{ppm}$ & 8.16 & 130.91 & 11.16 \\
\hline T7: Ethephon $250 \mathrm{ppm}$ & 7.45 & 123.77 & 10.55 \\
\hline $\mathrm{T}_{8}$ : Ethephon $500 \mathrm{ppm}$ & 7.23 & 120.15 & 10.45 \\
\hline $\mathrm{T}_{9}:$ Spermidine $50 \mathrm{ppm}$ & 7.52 & 124.96 & 10.66 \\
\hline $\mathrm{T}_{10}:$ Spermidine $100 \mathrm{ppm}$ & 7.59 & 126.15 & 10.76 \\
\hline $\mathrm{T}_{11}$ : Water spray (Control) & 7.16 & 119.01 & 10.15 \\
\hline Mean & 7.66 & 125.67 & 10.74 \\
\hline S.Em & 0.03 & 0.43 & 0.04 \\
\hline C.D. at $5 \%$ & 0.08 & 1.27 & 0.11 \\
\hline
\end{tabular}

GA3: Gibberellic acid; SA: Salicylic acid; BA: Benzyl Adenine

\section{Bulb yield}

Significant differences were noticed among different plant bioregulators for bulb yield ha-1 (Table 2). Bulb yield varied significantly due to the application of $\mathrm{GA}_{3}$ compared to the other plant bioregulators under study. Plants sprayed with $\mathrm{GA}_{3} 200 \mathrm{ppm}$ produced the highest bulb yield of $11.57 \mathrm{t}$ while the lowest yield of $10.15 \mathrm{t}$ was registered in plants sprayed with water (Control). These findings are in agreement with the results found by Jamil et al. (2015) ${ }^{[8]}$ in amaryllis who recorded the highest bulb yield $\left(40.56 \mathrm{t} \mathrm{ha}^{-1}\right)$ with $\mathrm{GA}_{3}$ at 500 ppm. It might be due to an efficient transportation of photoassimilates towards the growing daughter bulbs which lead to an increase in bulb yield ha ${ }^{-1}$. Similarly, Devadanam et al. (2007) ${ }^{[7]}$ and Shanker et al. (2011) ${ }^{[19]}$ also registered highest bulb yield ha ${ }^{-1}$ with $\mathrm{GA}_{3}$ in tuberose.
Further, it could be implied from the present study is that for both floret and bulb production foliar spray of $\mathrm{GA}_{3}$ is best followed by SA for floret yield and BA for bulb production.

\section{Economics}

Economic analysis of different plant bioregulators revealed variation in profitability of tuberose (Table 3). Total cost of cultivation varied due to the variation in the cost of bioregulating chemicals. Due to the variation in the floret and bulb yield as influenced by different bioregulators, gross returns also varied. Hence benefit - cost ratio exhibited a wide variation among the treatments. The highest yield, gross and net returns were obtained by $\mathrm{GA}_{3} 200 \mathrm{ppm}$ followed by $\mathrm{GA}_{3} 100$ ppm with highest benefit - cost ratio of 3.02 and 3.00 respectively. 
Table 3: Effect of plant bioregulators on economics of tuberose cv. Prajwal

\begin{tabular}{|c|c|c|c|c|c|c|}
\hline \multirow{2}{*}{ Treatments } & \multirow{2}{*}{ Total cost (₹) } & \multicolumn{2}{|c|}{ Gross return (₹) } & \multirow{2}{*}{ Total Gross return (₹) } & \multirow{2}{*}{ Net return (₹) } & \multirow{2}{*}{ Benefit-cost ratio } \\
\cline { 3 - 4 } & & Floret & Bulb & & & \\
\hline $\mathrm{T}_{1}:$ Gibberellic Acid 100 & 542308 & 944800 & 682200 & 1627000 & 1084692 & 3.00 \\
\hline $\mathrm{T}_{2}$ : Gibberellic Acid 200 & 548596 & 961600 & 694200 & 1655800 & 1107204 & 3.02 \\
\hline $\mathrm{T}_{3}$ : Salicylic Acid 50 ppm & 535577 & 923200 & 651600 & 1574800 & 1039224 & 2.94 \\
\hline $\mathrm{T}_{4}:$ Salicylic Acid 100 ppm & 536093 & 928000 & 657600 & 1585600 & 1049507 & 2.96 \\
\hline $\mathrm{T}_{5}:$ Benzyl Adenine 50 ppm & 536358 & 902400 & 666000 & 1568400 & 1032042 & 2.92 \\
\hline $\mathrm{T}_{6}:$ Benzyl Adenine 100 ppm & 540136 & 911200 & 669600 & 1580800 & 1040664 & 2.93 \\
\hline $\mathrm{T}_{7}:$ Ethephon 250 ppm & 531556 & 877600 & 633000 & 1510600 & 979044 & 2.84 \\
\hline $\mathrm{T}_{8}$ : Ethephon 500 ppm & 528452 & 840800 & 627000 & 1467800 & 939348 & 2.78 \\
\hline $\mathrm{T}_{9}:$ Spermidine 50 ppm & 596072 & 885600 & 639600 & 1525200 & 929128 & 2.56 \\
\hline $\mathrm{T}_{10}$ :Spermidine 100 ppm & 661244 & 894400 & 645600 & 1540000 & 878756 & 2.33 \\
\hline $\mathrm{T}_{11}:$ Water spray (Control) & 530100 & 868800 & 609000 & 1477800 & 947700 & \\
\hline
\end{tabular}

\section{Conclusion}

After going through the results obtained in the investigation, it is inferred that the floret and bulb production of tuberose were maximum in the plants sprayed with $\mathrm{GA}_{3} 200 \mathrm{ppm}$ with highest net returns (Rs. $1107204 \mathrm{ha}^{-1}$ ) and $\mathrm{B}$ : C ratio (3.02). Hence, two foliar sprays of $\mathrm{GA}_{3} 200 \mathrm{ppm}$ at 30 and $60 \mathrm{DAS}$ is recommended to obtain higher economic yield and returns in tuberose cv. Prajwal.

\section{References}

1. Aier S, Langthasa S, Hazarika DN, Gautam BP, Goswami RK. Influence of $\mathrm{GA}_{3}$ and $\mathrm{BA}$ on morphological, phenological and yield attributes in gladiolus cv. Red Candyman. Journal of Agriculture and Veterinary Science. 2015; 8(6):37-42.

2. Anwar M, Sahito HA, Hassan I, Abbasi NA, Ahmed HA, Bhatti MA et al. Effect of pre harvest treatment of salicylic on growth and vase life of tuberose with aroma environment. Wudpecker J. Agric Res. 2014; 3(2):50-57.

3. Audus LJ. Plant Growth Substances, Chemistry and Physiology. Vol. I, Leonard Hill, London, 1972, 533.

4. Brooking IR, Cohen D. Gibberellin-induced flowering in small tubers of Zantedeschia 'Black Magic'. Scientia Horticulturae. 2002; 95(1-2):63-73.

5. Chase AR. Effect of fertilizer rate on growth response of Codiaeum variegatum (Gold Star). Foliage Digest. 1989; 12:7-8.

6. Chopde N, Patil A, Bhande MH. Growth, yield and quality of gladiolus as influenced by growth regulators and methods of application. Plant Archives. 2015; 15(2):691-694.

7. Devadanam A, Sable PB, Shinde BN, Haldewad AM. The effects of foliar spray of plant growth regulators on growth and yield tuberose (Polianthes tuberose L).J. Maharashtra Agric. Univ. 2007; 32(2):282-283.

8. Jamil MK, Rahman MM, Hossain MM, Hossain MT, Karim AJMS. Effect of plant growth regulators on flower and bulb production of hippeastrum (Hippeastrum hybridum Hort.). Bangladesh J Agr Res. 2015; 40(4):591600.

9. Khan NA, Singh S, Nazar R, Lone PM. The source-sink relationship in mustard. Asian Australas. J. Biosci. Biotechnol. 2007; 1:10-18.

10. Khodakhah B, Nabigol A, Salehi B. The effect of different levels of humic acid and salicylic acid on growth characteristics and qualities of tuberose. Adv. Environ. Biol. 2014; 8(16):118-123.

11. Kim YH, Hamayun M, Khan AL, Na CI, Kang SM, Han $\mathrm{HH}$ et al. Exogenous application of plant growth regulators increased the total flavonoid content in
Taraxacum officinale (Wigg). Afr. J. Biotechnol. 2009; 8:5727-5732.

12. Kurve G. Effect of plant growth regulators on growth and flowering of tuberose (Polianthes tuberose Linn.). M.Sc. Thesis. Rajmata Vijayaraje Scindia Krishi Vishwa Vidyalaya, Gwalior, India, 2016.

13. Machado IE, Escobedo GMRM, Saavedra AL. Responses of transformed Catharanthus roseus roots to femtomolar concentrations of salicylic acid. Plant Physiol Bioch. 2007; 45:501-507.

14. NHB. Indian Horticulture Database 2014. IG Printer Pvt. Ltd. New Delhi. 2015, 286. www.nhb.gov.in

15. Padaganur VG, Mokashi AN, Patil, VS. Effect of growth regulators on growth and yield of tuberose cv. Single. Karnataka Journal of Agricultural Sciences. 2005; 18(2):469-473.

16. Panse VG, Sukhatme PV. Statistical Methods for Agricultural Workers. Indian Council for Agricultural Research, New Delhi. 1989, 359.

17. Pierik R, Sasidharan R, Voesenek LACJ. Growth control by ethylene: Adjusting phenotypes to the environment. J. Plant Growth Regul. 2007; 26:188-200.

18. Rani P, Singh P. Impact of gibberellic acid pretreatment on growth and flowering of tuberose (Polianthes tuberosa L.) cv. Prajwal. Journal of Tropical Plant Physiology. 2013; 5:33-41.

19. Shanker K, Singh AK, Singh HK. Effect of plant growth regulators on spike yield and bulb production of tuberose (Polianthus tuberosa Linn) Double. Plant Archives. 2011; 11(1):169-671.

20. Singh AK, Bijimol G. Influence of growth regulating chemicals on growth, flowering and bulb production in tuberose (Polianthes tuberose L.). Indian perfumer. 2001; 45(1):31-34.

21. Singh AK. Response of tuberose growth, flowering and bulb production to plant bio-regulators spraying. Progressive Horticulture. 1999; 31(3-4):181-183.

22. Singh PK, Singh DB, Singh SN. Effect of $\mathrm{GA}_{3}$ and NAA on plant growth, flowering, bulb production and vase life of tuberose (Polianthes tuberosa L.) cv. Single. Research in Environment and Life Sciences. 2013; 6(4):137-140.

23. Singh PK, Singh SN, Singh DB. Response of $\mathrm{GA}_{3}$ and NAA on growth, flowering, bulb production and vase life of tuberose (Polianthes tuberosa L.) cv. Single. The Asian Journal of Horticulture. 2008; 3(1):183-186.

24. Singh R, Goyal RK, Gupta AK. Effect of plant growth regulators on germination, flowering and bulb production in tuberose (Polianthes tuberosa L.) cv. Double. Haryana Journal of Horticultural Sciences. 2010; 39(3/4):310-312. 
25. Srivastava AK, Pasala R, Minhas PS, Suprasanna P. Plant Bioregulators for Sustainable Agriculture: Integrating Redox Signaling as a Possible Unifying Mechanism. Adv. Agron. 2016; 137:237-238.

26. Zieslin N, Brian I, Halevy AH. The effect of growth regulators on growth and pigmentation of Baccara rose flowers. Plant Cell Physiol.1974; 15(2):341-349. 